Research Journal of Applied Sciences, Engineering and Technology 5(21): 5119-5121, 2013

DOI:10.19026/rjaset.5.4407

ISSN: 2040-7459; e-ISSN: 2040-7467

(C) 2013 Maxwell Scientific Publication Corp.

\begin{tabular}{lll}
\hline Submitted: November 19, 2012 & Accepted: January 01, 2013 & Published: May 20, 2013
\end{tabular}

\title{
Research Article \\ Willing to Pay in Urban Forests, Finance Support from Public Case Study, Shorab Urban Forest in Khoram Abad, Iran
}

\author{
${ }^{1}$ Rahim Maleknia, ${ }^{1}$ Mohsen Nourzad Moghaddam, ${ }^{2}$ Shirzad Geraili, ${ }^{1}$ Fatemeh Azizi and \\ ${ }^{1}$ Samaneh Razm Ahang \\ ${ }^{1}$ Department of Forestry Science, Lorestan University, Lorestan, Iran \\ ${ }^{2}$ Department of Forestry Science, University of Tehran, Tehran, Iran
}

\begin{abstract}
The goal of this study is to estimate the visitors' willingness to pay at Shorab Urban Forest. The dichotomous choice Contingent Valuation Method (CVM) was used to estimate the Willingness To Pay (WTP). A total of 210 respondents were interviewed via a questionnaire method in two periods to gather the data. Respondents also were asked the maximum amount they are willing to pay for entrance fee. Probit model was used to determine WTP. Results showed that different genders, ages and educational levels are using this park for recreational aim. Probit model showed that the average willingness to pay was 1325 Tomans. Since the family size average was 4.35 , monthly entrance fee for every family was estimated at 5763 Tomans.
\end{abstract}

Keywords: Lorestan, probit model, shorab, urban forest, willing to pay

\section{INTRODUCTION}

Tourism is the world's fastest growing industry and its fastest growing component is ecotourism. Growth of Natural resources based recreation as one of the important types of recreation is estimated at $10-15 \%$ annually (Lindberg, 2001). In the other side, all the indicators show that central government funding for conservation is likely to be reduced (White and Lovett, 1999). Tourism offers the potential to provide economic development, through the provision of increased income and employment, conserving nature and funding for maintenance of natural recreation area.

Ecotourism probably is main means of insuring the self-financing of protected areas (McNeely, 1994; Dharmaratne et al., 2000).

This system and self-financing also can be used in urban natural forests. Urban forests are reported to produce multiple benefits including air pollution reduction, climate Moderation and recreational opportunities (Konijnendijk et al., 2006). In another hands, people from urban area are more interest with the ecotourism resources especially urban forests or park in or neat to cities because these conditions are hard to exist in urban area (Shamsudin et al., 2009).

Urban forests management needs public participation. There are different methods for people participating in natural resource management. Use of the constructed or hypothetical market approach is a method in which people can pay money for using ecological services and goods (Samdin, 2008). This market is usually enacted in the form of fees, which are considered as realistic and desirable on the part of the public payment vehicle (White and Lovett, 1999; Lee and Han, 2002). Before establishing fees, urban authorities have to investigate visitors' Willingness To Pay (WTP). The willingness to pay is the maximum amount a person would be willing to pay, sacrifice or exchange in order to receive a good or to avoid something undesired. This is answer from market or public to conservation and well management of natural resources and urban forests. It measures whether an individual is willing to forego their income in order to obtain more goods and services and is typically used for non-market goods. The Contingent Valuation Method (CVM) is an example of stated preference methods, which are most commonly used to gauge environmental and recreational value of natural parks and urban forests. CVM relies on using a questionnaire that taps the Willingness To Pay (WTP) for a non-market functions, which is based on a survey of respondents using hypothetical questions (Ghanbarpour et al., 2011).

This study therefore investigated public willingness-to-pay for the ecosystem services of an urban forest with Shorab Khoram Abad as a focus. The information provided will assist managers and users to make informed decisions and plausible trade-off on urban forest investment.

Corresponding Author: Rahim Maleknia, Department of Forestry Science, Lorestan University, Lorestan, Iran

This work is licensed under a Creative Commons Attribution 4.0 International License (URL: http://creativecommons.org/licenses/by/4.0/). 


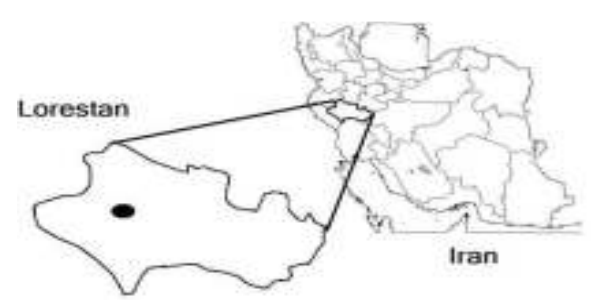

Fig. 1: Study area

\section{MATERIAL AND METHODS}

Study area: This study was conducted in Shorab urban forest as a case study. Shorab as an urban park is located in $25 \mathrm{~km}$ distance of Khoram Abad city (Fig. 1). With area of 1293 ha, Shorab is one the biggest urban forest in Iran. Oak and pines are common tree spices in park.

Data collection: Due to lack of data as to the size of the target population, probabilistic sampling techniques could not be applied. The sample was randomly selected from visitors accessing park. And a total of 210 visitors were requested to take part in this study.

A questionnaire was designed to collect information on WTP in this study. The Survey questionnaire was chosen because it encourages high response rates, provides assistance to respondents and is suitable for complex questions. The survey was conducted over two periods including 9-15 march and 2-8 June. These periods belong to different seasons and provide better sampling. The average time taken for the survey was about 20-30 min.

The questionnaire was divided into three sections: personal characteristics including age, gender, marital status, education and income, variables related to urban forest management and Characteristics of paying.

In later section respondents were asked whether they are willing to pay for entrance fee. The question was posed to discover the willingness of visitors to pay. This approach is called a 'bidding game' and involved three different levels of fee; low, medium and high. These level were chosen based on a pre-survey and interview with some visitors and experts. The respondents were asked if they are willing to pay 3000 Tomans (Currency of Iran) as entrance fee. The bid level was increase to 4000 if they reply positively, but if they reply negatively the bid level was decreased. The respondents also were asked to state the maximum or minimum entrance fee they are willing to pay.

Statistical Package for Social Sciences (SPSS) was chosen to analyze the visitors' data. Descriptive analyses such as mean and frequencies were applied to obtain information on socio demographic and economic profiles and respondents' WTP. Also Probit model was used to estimate the WTP:
Table 1: Visitors' profile

\begin{tabular}{lll}
\hline Characteristic & Percentage & $\mathrm{n}$ \\
\hline Gender & 59 & 123 \\
Male & 41 & 87 \\
Female & & \\
Age & 14 & 29 \\
$0-25$ & 42 & 88 \\
$25-40$ & 34 & 71 \\
$40-55$ & 10 & 21 \\
$>55$ & & \\
Educational level & 1 & 2 \\
No formal education & 9 & 19 \\
School & 38 & 80 \\
Diploma & 45 & 95 \\
Bachelor & 7 & 15 \\
M.Sc./PhD & &
\end{tabular}

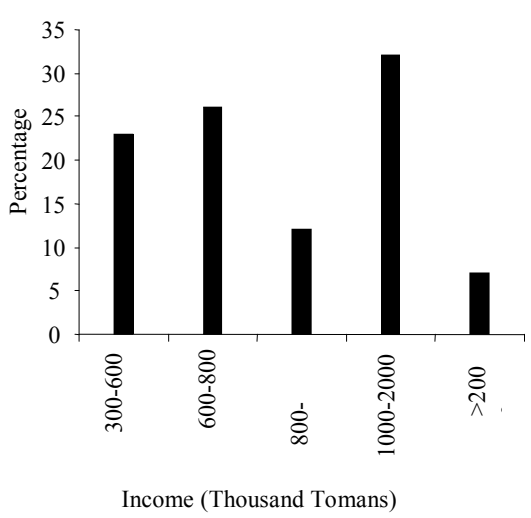

Fig. 2: Family income of visitors

$$
E(W T P)=\int_{0}^{20000}\left(\frac{1}{1+\exp \left[\left(\begin{array}{c}
-(0 / 985- \\
0.0003055 b i d
\end{array}\right)\right]}\right) d b i d
$$

\section{RESULTS}

Visitors' profiles: Table 1 shows the summary of visitors' profile. With respect to the age, the visitors of Shorab consist of various levels of age. The results indicated that the respondents' ages ranged from 0 to 85 year old. Most of respondents interviewed are in the range of 25-40 years old (42\%). This was followed by those in 40-55 years old (34\%), below 25 years old (14 percent) and the fewest of respondents interviewed was those above 55 years old (10\%). By gender, the majority of Visitors (59\%) were male. More than half $(41 \%)$ were married. majority of visitors $(89 \%)$ earned an income of less than 1 million Tomans (Fig. 2).

Family size is shown in Fig. 3. Families with 4 and 5 members consist more than $60 \%$ together.

Willing to pay: Figure 4 shows the WTP for in individual scale. Generally, study found that $83 \%$ of the respondents were willing to pay the given bids, while $17 \%$ were not willing to pay. The Probit model shows that the average willingness to pay was 1325 Tomans. Since the family size average was 4.35 (Table 2), 


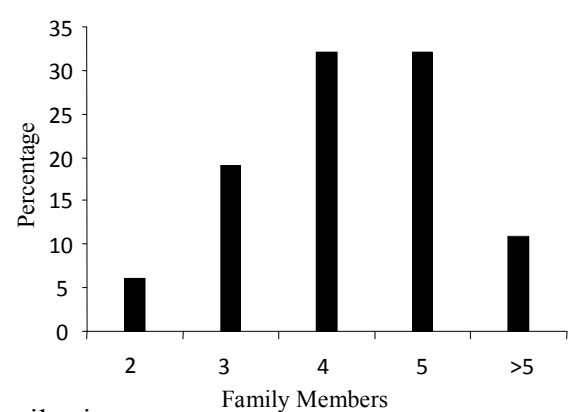

Fig. 3: Family size

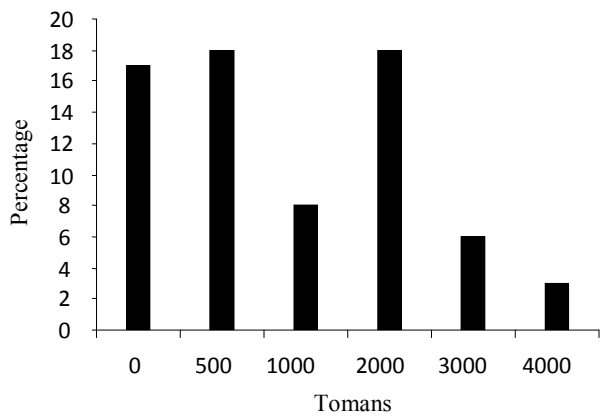

Fig. 4: Willing to pay

\begin{tabular}{lccll}
\multicolumn{4}{l}{ Table 2: Probit results on factors influencing value addition } \\
\hline Variable & Coefficient & t-value & Significance & $\begin{array}{l}\text { Marginal } \\
\text { effects }\end{array}$ \\
\hline $\begin{array}{l}\text { Age } \\
\text { Household } \\
\text { size }\end{array}$ & -0.002022 & -0.2662 & 0.007595 & 0.0005773 \\
$\begin{array}{l}\text { Household } \\
\text { income }\end{array}$ & 0.20424 & 1.6079 & 0.127 & 0.07649 \\
$\begin{array}{l}\text { Educational } \\
\text { level }\end{array}$ & 0.317165 & 2.4751 & 0.05319 & 0.04929 \\
\hline
\end{tabular}

monthly entrances fee for every family was estimated at 5763 Tomans.

\section{CONCLUSION}

Public finance support is a policy that can be used to enhance the management of Natural parks and Urban Forest for their non-market goods. In this study, visitors' willingness to pay has been analyzed for entrance fees in Shorab urban forest. Samdin (2008) suggests that WTP is one of the sources of protected areas and a huge flow of finance has come from individual's WTP. As results show, more than $80 \%$ of visitors agree to pay entrance fee. The mean Entrance fee was estimated 5763 Tomans in family scale. The size of the income from recreational areas, which provides the means of improvement, depends largely on the attractions and facilities at the site. Since the urban forest attracts many visitors per year, this fee can be used to enhance the management of urban forest in different ways. One strategy is to develop more facilities for vehicles, designing new parking spaces and creating suitable spaces for attracting tourists. These attempts can result in more public participation in forest management. Less than $20 \%$ of visitors did not accept to pay fee, educational program may increase public's awareness about urban forests and encourage this group to help park management via finance support in form of entrance fee.

\section{REFERENCES}

Dharmaratne, G.S., F. Yee Sang and L.J. Walling, 2000. Tourism potentials for financing protected areas. Ann. Tourism Res., 27: 590-610.

Ghanbarpour, M.R., S. Sajjadi, S.T. Hajiseyedjavadi and Z. Chen, 2011. Investigation of visitors' participation and willingness to pay for the Baba Aman recreational park, Iran. Res. J. Environ. Earth Sci., 3(6): 722-728.

Konijnendijk, C.C., R.M. Ricard, A. Kenney and T.B. Randrup, 2006. Defining urban forestry-A comparative perspective of North America and Europe. Urban Forest. Urban Green., 4(3-4): 93-103.

Lee, C.K. and S.Y. Han, 2002. Estimating the use and preservation values of national parks' tourism resources using a contingent valuation method. Tourism Manage., 23: 531-540.

Lindberg, K., 2001. Economic Impacts. In: Weaver, D. (Ed.), the Encyclopedia of Ecotourism. CABI Publishing, Wallingford and New York, pp: 363-377.

McNeely, J.A., 1994. Protected areas for the 21st century: Working to provide benefits to society. Biodivers. Conserv., 3: 390-405.

Samdin, Z., 2008. Willingness to pay in Taman Negara: A contingent valuation method. Int. J. Econ. Manage., 2(1): 81-94.

Shamsudin, M.N., A. Radam and A. Shuib, 2009. Willingness to pay towards the conservation of ecotourism resources at Gunung Gede Pangrango National Park, West Java, Indonesia. J. Sustain. Dev., 2(2): 173-186.

White, P.C.L. and J.C. Lovett, 1999. Public preferences and willingness to pay for nature conservation in the North York moors National Park, UK. J. Environ. Manage., 55: 1-13. 